\title{
Treatment of Hypertension
}

\section{Wilbert S Aronow*}

Division of Cardiology, Westchester Medical Center/New York Medical College, NY, USA

Hypertension is a major risk factor for cardiovascular events [1,2]. Hypertension is present in approximately $69 \%$ of patients with a first myocardial infarction [3], in approximately $77 \%$ of patients with a first stroke [3], in approximately $74 \%$ of patients with heart failure [3], and in $60 \%$ of patients with peripheral arterial disease [4]. Hypertension is also a major risk factor for a dissecting aortic aneurysm, sudden cardiac death, angina pectoris, atrial fibrillation, diabetes mellitus, the metabolic syndrome, chronic kidney disease, thoracic and abdominal aortic aneurysms, left ventricular hypertrophy, vascular dementia, Alzheimer's disease, and ophthalmologic disorders [2].

The 2009 European Society of Hypertension guidelines recommended that lowering the blood pressure to less than $130 / 80 \mathrm{~mm} \mathrm{Hg}$ in patients at high risk for cardiovascular events was unsupported by prospective trial data, and that the systolic blood pressure should be lowered to less than $140 \mathrm{~mm} \mathrm{Hg}$ in these patients [5]. The American College of Cardiology Foundation/American Heart Association 2011 expert consensus document on hypertension in the elderly recommended that the blood pressure should be lowered to less than $140 / 90 \mathrm{~mm} \mathrm{Hg}$ in adults younger than 80 years at high risk for cardiovascular events [2]. On the basis of data from the Hypertension in the Very Elderly trial [6], these guidelines recommended that the systolic blood pressure should be reduced to 140 to $145 \mathrm{~mm} \mathrm{Hg}$ if tolerated in adults aged 80 years and older. I concur with this guidelines [2,7-11].

The following studies discuss the reasons for my recommendations [12-19]. A meta-analysis of 147 randomized trials including 464,000 persons with hypertension showed that except for the extra protective effect of beta blockers given after myocardial infarction and a minor additional effect of calcium channel blockers in preventing stroke, the use of beta blockers, angiotensin-converting enzyme (ACE) inhibitors, angiotensin receptor blockers (ARBs), diuretics, and calcium channel blockers cause a similar reduction in coronary events and stroke for a given decrease in blood pressure [20]. The proportionate reduction in cardiovascular events was the same or similar regardless of pretreatment blood pressure and the presence or absence of cardiovascular events [20], Diuretics, ACE inhibitors, ARBs, calcium channel blockers, or beta blockers may be used as initial therapy in the treatment of primary hypertension in older and in younger persons. If beta blockers are used, beta blockers such as carvedilol, nebivolol, and bisoprolol are preferred [21].

The American College of Cardiology Foundation/American Heart Association 2011 expert consensus document on hypertension in the elderly recommended that diuretics, ACE inhibitors, ARBs, beta blockers, and calcium channel blockers have all demonstrated benefit in reducing cardiovascular events in randomized trials [2]. The choice of specific antihypertensive drugs depends on efficacy, tolerability, presence of specific comorbidities, and cost [2].

In conclusion, the blood pressure should be lowered to less than $140 / 90 \mathrm{~mm} \mathrm{Hg}$ in adults younger than 80 years at high risk for cardiovascular events [2], On the basis of data from the Hypertension in the very elderly trial [6], the systolic blood pressure should be reduced to 140 to $145 \mathrm{~mm} \mathrm{Hg}$ if tolerated in adults aged 80 years and older.

\section{References}

1. Chobanian AV, Bakris GL, Black HR, Cushman WC, Green LA, et al. (2003) The Seventh Report of the Joint National Committee on Prevention, Detection, Evaluation, and Treatment of High Blood Pressure. the JNC 7 Report. JAMA 289: $2560-2572$.

2. Aronow WS, Fleg JL, Pepine CJ, Artinian NT, Bakris G, et al. (2011) ACCF/AHA 2011 expert consensus document on hypertension in the elderly: a report of the American College of Cardiology Foundation Task Force on Clinical Expert Consensus documents developed in collaboration with the American Academy of Neurology, American Geriatrics Society, American Society for Preventive Cardiology, American Society of Hypertension, American Society of Nephrology, Association of Black Cardiologists, and European Society of Hypertension. J Am Coll Cardiol 57: 2037-2114.

3. Lloyd-Jones D, Adams R, Carnethon M, De Simone G, Ferguson TB, et al. (2009) Heart disease and stroke statistics-2009 update: a report from the American Heart Association Statistics Committee and Stroke Statistics Subcommittee. Circulation 119: e21-e181.

4. Aronow WS, Ahmed MI, Ekundayo OJ, Allman RM, Ahmed A (2009) A propensity-matched study of the association of peripheral arterial disease with cardiovascular outcomes in community-dwelling older adults. Am J Cardiol 103: 130-135.

5. Mancia G, Laurent S, Agabiti-Rosei E, Ambrosioni E, Burnier M, et al. (2009) Reappraisal of European guidelines on hypertension management: a European Society of Hypertension Task Force document. Blood Press 18: 308-347.

6. Beckett NS, Peters R, Fletcher AE, Staessen JA, Liu L, et al. (2008) Treatment of hypertension in patients 80 years of age or older. N Eng J Med 358: 1887-1898.

7. Aronow WS (2011) Hypertension guidelines. Hypertension 58: 347-348.

8. Banach M, Aronow WS (2011) Should we have any doubts about hypertension therapy in elderly patients?: ACCF/AHA 2011 expert consensus document on hypertension in the elderly. Pol Arch Med Wewn 121: 253-258.

9. Aronow WS, Banach M (2012) Ten most important things to learn from the ACCF/ AHA 2011 expert consensus document on hypertension in the elderly. Blood Pressure 21: 3-5

10. Aronow WS (2011) Ten key points from the American College of Cardiology Foundation/American Heart Association 2011 expert consensus document on hypertension in the elderly. Am J Ther.

11. Banach M, Aronow WS (2012) Hypertension therapy in the older adults-do we know the answers to all the questions? The status after publication of the ACCF/ AHA 2011 expert consensus document on hypertension in the elderly. J Hum Hypertens 26: 641-643.

12. Bangalore S, Qin J, Sloan S, Murphy SA, Cannon CP, et al. (2010) What is the optimal blood pressure in patients after acute coronary syndromes? Relationship of blood pressure and cardiovascular events in the Pravastatin or Atorvastatin Evaluation and Infection Therapy-Thrombolysis in Myocardial Infarction (PROVE IT-TIMI) 22 trial. Circulation 122: 2142-2151.

*Corresponding author: Wilbert S. Aronow, Professor of Medicine, Division of Cardiology, Westchester Medical Center/New York Medical College, NY, USA, Tel: (914) 493-5311; Fax: (914) 235-6274; E-mail: wsaronow@aol.com

Received November 17, 2012; Accepted November 18, 2012; Published November 20, 2012

Citation: Aronow WS (2012) Treatment of Hypertension. Cardiol Pharmacol 1:e103. doi:10.4172/2329-6607.1000e103

Copyright: (c) 2012 Aronow WS. This is an open-access article distributed under the terms of the Creative Commons Attribution License, which permits unrestricted use, distribution, and reproduction in any medium, provided the original author and source are credited. 
13. Cooper-DeHoff RM, Gong Y, Handberg EM, Bavry AA, Denardo SJ, et al. (2010) Tight blood pressure control and cardiovascular outcomes among hypertensive patients with diabetes and coronary artery disease. JAMA 304: 61-68.

14. ACCORD Study Group, Cushman WC, Evans GW, Byington RP, Goff Dc Jr, et al. (2010) Effects of intensive blood-pressure control in type 2 diabetes mellitus. N Engl J Med 362: 1575-1585

15. Mancia G, Schumacher H, Redon J, Verdecchia P, Schmieder R, et al (2011) Blood pressure targets recommended by guidelines and incidence of cardiovascular and renal events in the Ongoing Telmisartan Alone and in Combination With Ramipril Global Endpoint Trial (ONTARGET). Circulation 124 $1727-1736$.

16. Redon J, Mancia G, Sleight P, Schumacher H, Gao P, et al. (2012) Safety and efficacy of low blood pressures among patients with diabetes: Subgroup analyses from the ONTARGET (ONgoing Telmisartan Alone and in combination with Ramipril Global Endpoint Trial). J Am Coll Cardiol 59: 74-83.
17. Upadhyay A, Earley A, Haynes SM, Uhlig K (2011) Systematic review: blood pressure target in chronic kidney disease and proteinuria as an effect modifier. Ann intern Med 154: 541-548.

18. Ovbiagele B, Diener HC, Yusuf S, Martin RH, Cotton D, et al. (2011) Level of systolic blood pressure within the normal range and risk of recurrent stroke. JAMA 306: 2137-2144

19. Banach M, Bhatia V, Feller MA, Mujib M, Desai RV, et al. (2011) Relation of baseline systolic blood pressure and long-term outcomes in ambulatory patients with chronic mild to moderate heart failure. Am J Cardiol 107: 1208-1214.

20. MR, Morris JK, Wald NJ (2009) Use of BP lowering drugs in the prevention of cardiovascular disease: meta-analysis of 147 randomised trials in the context of expectations from prospective epidemiological studies. BMJ 338: b1665.

21. Aronow WS (2010) Current role of beta-blockers in the treatment of hypertension. Expert Opin Pharmacother 11: 2599-2607. 